\title{
Physicochemical and Bacteriological Qualities of Groundwater from Some Localities in the Adamawa Region of Cameroon
}

\author{
${ }^{1} \mathrm{Ahmed}$ Ali, ${ }^{2}$ Bouba Adji Mohamadou and ${ }^{1} \mathrm{Clement}$ Saidou \\ ${ }^{1}$ Department of Chemical Engineering, ${ }^{2}$ Department of Food Engineering and Quality Control, \\ University Institute of Technology Ngaoundere, \\ P.O. Box 454 Ngaoundere, Cameroon
}

\begin{abstract}
The present research was carried out to assess the chemical and microbiological safety of groundwater from eight sampling points in the Adamawa region of Cameroon. Some physicochemical parameters (turbidity, conductivity, alkalinity, total dissolved solids and $\mathrm{pH}$ ) were determined using standard methods. Minerals and heavy metals were analyzed using Atomic Absorption spectrophotometer while pathogens and waterborne bacteria were screened according to reference methods. Results showed that most physicochemical parameters $(\mathrm{pH}$, salinity, calcium, magnesium, chloride, sulfate and phosphate $)$ were acceptable with regard to existing norms. However, some samples exhibited values above these norms. Turbidity and suspended matter were higher than recommended for drinking water in most samples. Fortunately, no heavy metal was detected in water from the eight localities. With regard to bacteriological safety, only one sample (Mbe) was not contaminated with pathogenic microorganisms. Those collected in Belel appeared to be contaminated by such pathogens as clostridia, Fecal coliforms, Fecal streptococci, salmonella and shigella and Staphylococcus aureus. Neither pseudomonas, nor vibrio was detected. At the whole, the study revealed that groundwater from covered wells, generally considered as safe and potable, needs to be treated prior consumption and use.
\end{abstract}

Key words: Groundwater, physicochemical properties, bacterial contamination, safety, consumptions, Cameroon

\section{INTRODUCTION}

Cameroon, situated in the center of Africa is blessed with different climatic and agro-ecological zones with very diverging climates and geography. These include the forest, the mountains and the savannah. Hence, water sources for domestic and agricultural activities largely depend on the agro-ecological zone. In the forestry and highlands regions of Cameroon, water is easily accessible from lakes, rivers and springs. However, in the sudano-sahelian zone which includes the Adamawa region, people get drinking water from traditional open wells characterized by a diameter of about $1 \mathrm{~m}$. This poses the question of the quality of drinking water used for decades by local populations. Clearly, drinking water in rural areas of Cameroon hardly meets standards as noted by UNICEF. In effect, this United Nations agency estimates that only $51 \%$ of rural localities have access to improved drinking water in Cameroon while $2 \%$ of these localities use piped connections.
Moreover, this groundwater is used without any chemical or physical treatment especially in villages. Now a days, changes in population density (characterized by important growth) and habits (increasing use of chemical inputs in agriculture and animal husbandry) are impacting the environment in both rural and urban areas. One consequence could be the effect of human activity on groundwater reserve. This might considerably affect the overall quality of water. In this respect, recent studies carried out in Douala (Cameroon) revealed the high prevalence of water-borne diseases including parasitic and bacterial infections within populations (Ako et al., 2009). Investigations realized in the Adamawa region corroborate this trend with a dramatic consequence on school children. Garba and Mbofung (2010) revealed the high prevalence of waterborne parasites in this category of pupils: $43.8 \%$ were affected by schistosoma, $61.9 \%$ by entamoeba among other diseases. In the same light, recent developments in Cameroon with a dramatic outbreak of cholera clearly demonstrate the importance of drinking water quality for the consumers and for public health in general.

Corresponding Author: Ahmed Ali, Department of Chemical Engineering, University Institute of Technology Ngaoundere, P.O. Box 454 Ngaoundere, Cameroon 
Given the above, government and local authorities have put in place an overall strategy to increase the production of potable water in urban and rural areas. To this effect, covered wells are drilled in villages and water pumps installed to distribute this groundwater generally considered as potable. Despite the installation of such units, significant prevalence of water-borne diseases are still recorded among populations. The present research was therefore, designed to investigate the physicochemical and bacteriological qualities of groundwater from newly constructed wells in some villages of the Adamawa region of Cameroon.

\section{MATERIALS AND METHODS}

Description of water sampling area: The water sampling area is located in the Adamawa region of Cameroon in the heart of sudanian agro-ecological zone characterized by two different seasons: a rainy season (from May-September) and a longer dry season (from October-April). The region main activities are cattle rearing and agriculture. Water is generally fetched from open wells dug by villagers and used in domestic activities (drinking and cooking). These open wells are very often associated with water quality hazards due to exposure to the surrounding environment (and human activities). Recently, the local governments initiated a program of controlled and covered wells construction to provide people with good quality groundwater. In this program, eight wells were constructed in four localities including 5 in Belel ( $7^{\circ} 03^{\prime}$ North latitude and $14^{\circ} 26^{\prime}$ East longitude), 1 in Mbe ( $7^{\circ} 51 \mathrm{North}$ latitude and $13^{\circ} 35^{\prime}$ East longitude), 1 in Meiganga ( $6^{\circ} 31^{\prime}$ North latitude and $14^{\circ} 17^{\prime}$ East longitude) and 1 in Tignere ( $7^{\circ} 22^{\prime}$ North latitude and $12^{\circ} 39^{\prime}$ East longitude). With regard to human activities, Belel is a pasture zone with high concentration of cattle while Mbe, Meiganga and Tignere are more urbanized localities with little agriculture and livestock activities (Fig. 1).

Sampling: Groundwater samples were collected from eight wells (40-60 m depth) namely Goumdjel Troua, Walde Sodepa, Goumdjel Pastoral, Belel Chefferie, Belel Ecole, Mbe, Meiganga and Tignere. The first five sampling points are situated in the locality of Belel. Samples were collected using clean and sterile plastic bottles, transported in a cool box and kept at about $4^{\circ} \mathrm{C}$ for microbiological analyses. For mineral analyses about $5 \mathrm{~mL}$ of concentrated hydrochloric acid was added to $250 \mathrm{~mL}$ of each water sample and evaporated to $25 \mathrm{~mL}$. The concentrate was filtered using a cellulose membrane $(0.45 \mu \mathrm{m})$ and transferred to a $50 \mathrm{~mL}$ flask and diluted to mark with distilled water. The samples were then kept at about $4^{\circ} \mathrm{C}$.

Physicochemical analyses: Turbidity, $\mathrm{pH}$, conductivity and phosphates were determined according to the methods described by Nkansah et al. (2011). Some minerals and heavy metals ( $\mathrm{Ca}, \mathrm{Mg}, \mathrm{Cl}, \mathrm{Fe}, \mathrm{Co}, \mathrm{Cr}, \mathrm{Pb}, \mathrm{Cd}$ ) were analyzed Atomic Absorption (AAS 50B, Australia) as described by Ali et al. (2010). Total Dissolved Solids (TDS), alkalinity, $\mathrm{HCO}_{3}$ and $\mathrm{SO}_{4}$ were screened according to standard methods for the examination of water and wastewater (APHA, AWWA and WEF, 1999).

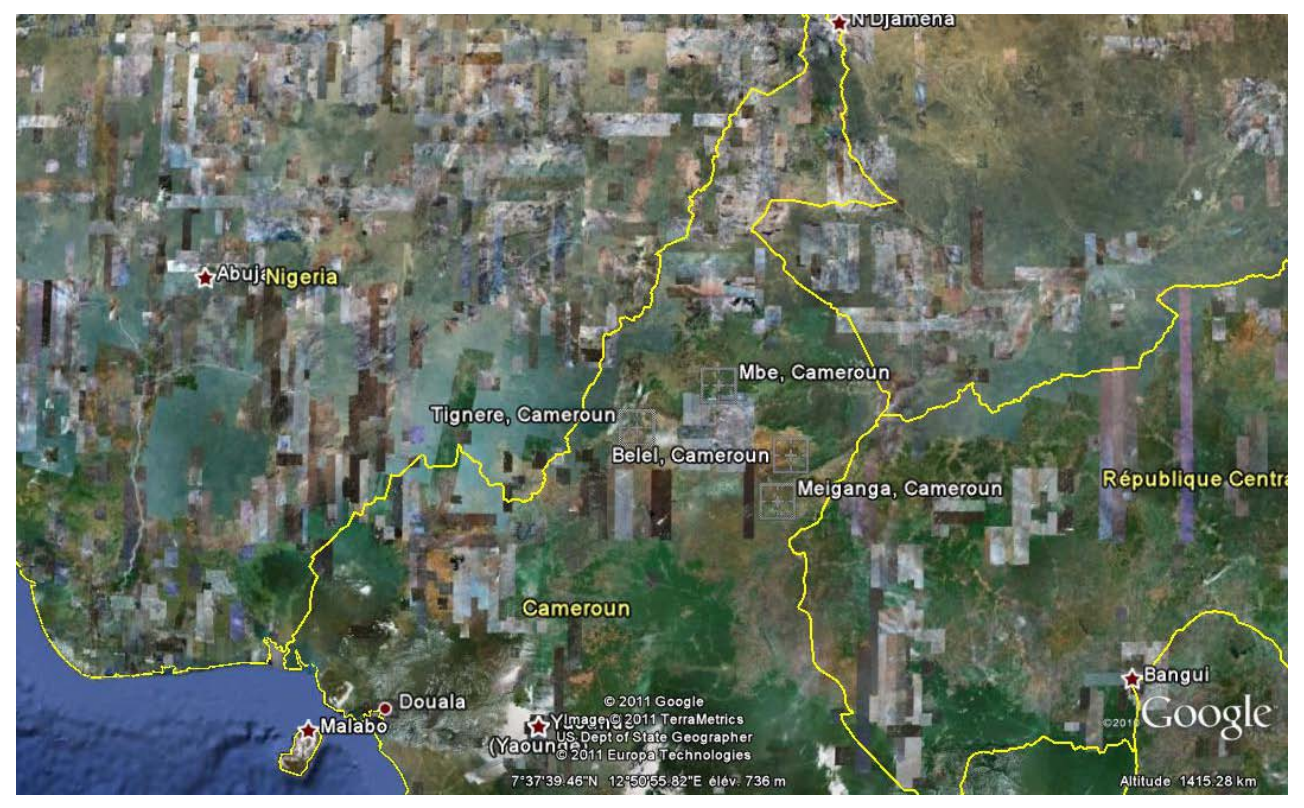

Fig. 1: Water sampling localities 
Bacteriological analyses: Quality indicators and pathogenic bacteria were screened respecting sampling methods and plating conditions and using appropriate culture media as recommended by AFNOR.

Statistical analyses: All the analyses were repeated three times. The results are expressed in means \pm standard deviations. Means were calculated using Microsoft Excel while correlations between water samples and their significance were obtained with Statistica for Windows (Manugistic Inc. Software, Rockville USA). A Principal Component Analysis (PCA) based on physicochemical and bacteriological quality of samples was carried out to classify samples using STATBOX 6.6 (Grimmersoft, France).

\section{RESULTS AND DISCUSSION}

The physico-chemical parameters were analyzed to present the overall aspect and chemical composition of groundwater from studied wells in the Adamawa region and are shown in Table 1.

The turbidity measured on the samples was higher than 05 Nephelometric Turbidity Unit (NTU) except for two villages, Meiganga and Tignere where values of about 1NTU were recorded. Turbidity measurements were therefore higher than recommended by WHO (1998) which estimate that water with a turbidity $<05$ NTU is acceptable to consumers. It is estimated that high turbidity may constitute health risk through protection of microorganisms from treatment and stimulation of microbial growth. Turbidity is the reflection of the total suspended matter to which it is inversely related on one hand and is an indication of clay and inert particles (Nkansah et al., 2011). This is corroborated by the amount of suspended matter measured. Thus, the two samples with the lower turbidity (Meiganga and Tignere) also had lower suspended matter with respective values of 0.03 and 0.04 .

The $\mathrm{pH}$ of the water fell within the acceptable WHO range of $7.5 \pm 1$ except for the sample from Belel Chefferie $(8.86 \pm 0.02)$. The lowest $\mathrm{pH}$ (6.76) was recorded in sample from Walde Sodepa. The effect of $\mathrm{pH}$ on water quality results in either taste complaints (for high $\mathrm{pH}$ ) or corrosion (acidic $\mathrm{pH}$ ). At the whole, water from Adamawa region exhibited high ph compared to groundwater from the Kwahu West District of Ghana (Nkansah et al., 2011).

Very low alkalinity was measured in samples. All values were $<1$ and very far from the WHO limit of $200 \mathrm{ppm}$. The lowest value was 0.04 while the highest was 0.71 . This traduces low concentrations of carbonates, bicarbonates. In this respect, six of the eight samples had low contents in $\mathrm{HCO}_{3}{ }^{-}$which ranged between $4.0 \pm 0.2$ and $31.41 \pm 1.01 \mathrm{mgL}^{-1}$. Two samples (Belel Chefferie and Belel Ecole) had higher concentrations of $\mathrm{HCO}_{3}{ }^{-}(150.06 \pm 10.12$ and $150.06 \pm 4.46 \mathrm{mg} \mathrm{L}^{-1}$, respectively).

The conductivity of all samples was below limit acceptable value of $2500 \mu \mathrm{s} \mathrm{cm}^{-1}$ (European Drinking Water Directive, 1998). The lowest and highest conductivities were $125.5 \pm 0.39$ and $1446.66 \pm 1.15$ $\mu \mathrm{sec} \mathrm{cm}^{-1}$ recorded, respectively in Goumdjel Pastoral and Tignere. The highest value, recorded for calcium was $45.29 \pm 1.98 \mathrm{mg} \mathrm{L}^{-1}$ for Goumdjel Pastoral while the

Table 1: Physic ochemical characteristics of groundwater from 8 localities

\begin{tabular}{|c|c|c|c|c|c|c|c|c|c|}
\hline \multirow[b]{2}{*}{$\begin{array}{l}\text { Physico-chemical } \\
\text { parameters }\end{array}$} & \multicolumn{9}{|l|}{ Village } \\
\hline & $\begin{array}{l}\text { Goumdjel } \\
\text { Troua } \\
\end{array}$ & $\begin{array}{l}\text { Goumdjel } \\
\text { Pastoral } \\
\end{array}$ & $\begin{array}{l}\text { Walde } \\
\text { Sodepa }\end{array}$ & Mbe & Meiganga & Tignere & $\begin{array}{c}\text { Belel } \\
\text { Chefferie }\end{array}$ & $\begin{array}{l}\text { Belel } \\
\text { Ecole }\end{array}$ & Norm \\
\hline Turbidity (NTU) & $11.6 \pm 0.1$ & $9.59 \pm 0.14$ & $174.57 \pm 3.43$ & $35.00 \pm 1.02$ & $1.2 \pm 0.4$ & $1.4 \pm 0.1$ & $11.16 \pm 1.02$ & $24.86 \pm 0.55$ & $05 \mathrm{NTU}$ \\
\hline $\mathrm{pH}$ & $8.22 \pm 0.16$ & $7.47 \pm 0.10$ & $6.76 \pm 0.12$ & $7.25 \pm 0.34$ & $6.93 \pm 0.05$ & $7.2 \pm 0.03$ & $8.86 \pm 0.02$ & $7.96 \pm 0.02$ & $6.5 \leq \mathrm{pH} \leq 8.5$ \\
\hline $\begin{array}{l}\text { Conductivity } \\
\left(\mu \mathrm{sec} \mathrm{cm}^{-1}\right)\end{array}$ & $269 \pm 1.73$ & $125.5 \pm 0.39$ & $167.30 \pm 0.02$ & $203.00 \pm 0.02$ & $456.00 \pm 1.73$ & $1446.66 \pm 1.15$ & $1219.66 \pm 7.12$ & $1299.33 \pm 12.04$ & $<2500 \mu \mathrm{sec} \mathrm{cm}^{-1}$ \\
\hline $\begin{array}{l}\text { Alkalinity } \\
\left(\mathrm{ppm} \mathrm{CaCO}_{3}\right)\end{array}$ & $0.12 \pm 0.00$ & $0.05 \pm 0.00$ & $0.04 \pm 0.00$ & $0.09 \pm 0.00$ & $0.21 \pm 0.01$ & $0.71 \pm 0.00$ & $0.6 \pm 0.0$ & $0.64 \pm 0.04$ & 200 \\
\hline TDS (mg L $\left.{ }^{-1}\right)$ & $0.2 \pm 0.01$ & $0.33 \pm 0.02$ & $1.13 \pm 0.51$ & $1.8 \pm 0.06$ & $0.03 \pm 0.00$ & $0.04 \pm 0.00$ & $5.33 \pm 1.56$ & $21.33 \pm 3.02$ & Not mentioned \\
\hline $\mathrm{Ca}^{2+}\left(\mathrm{mg} \mathrm{L}^{-1}\right)$ & $41.76 \pm 1.98$ & $45.29 \pm 1.98$ & $43.33 \pm 4.00$ & $37.34 \pm 2.14$ & $6.21 \pm 0.04$ & $21.04 \pm 0.12$ & $7.61 \pm 0.05$ & $7.73 \pm 0.91$ & $200 \mathrm{mg} \mathrm{L}^{-1}$ \\
\hline $\mathrm{Mg}^{2+}\left(\mathrm{mg} \mathrm{L}^{-1}\right)$ & $33.61 \pm 3.12$ & $35.65 \pm 2.55$ & $17.91 \pm 0.91$ & $13.34 \pm 0.13$ & $33.06 \pm 0.15$ & $107.72 \pm 0.15$ & $12.39 \pm 1.03$ & $11.90 \pm 0.90$ & $150 \mathrm{mg} \mathrm{L}^{-1}$ \\
\hline $\mathrm{HCO}_{3}^{-}\left(\mathrm{mg} \mathrm{L}^{-1}\right)$ & $8.00 \pm 0.05$ & $11.20 \pm 0.17$ & $15.66 \pm 1.89$ & $31.41 \pm 1.01$ & $11.00 \pm 0.12$ & $4.0 \pm 0.2$ & $150.06 \pm 10.12$ & $150.06 \pm 4.45$ & / \\
\hline $\mathrm{Cl}^{-}\left(\mathrm{mg} \mathrm{L}^{-1}\right)$ & $31.82 \pm 0.81$ & $31.82 \pm 0.81$ & $29.98 \pm 1.43$ & $7.23 \pm 0.75$ & $18.02 \pm 0.71$ & $26.73 \pm 1.04$ & $17.75 \pm 0.86$ & $14.2 \pm 1.9$ & $200 \mathrm{mg} \mathrm{L}^{-1}$ \\
\hline $\mathrm{Fe}^{2+}\left(\mathrm{mg} \mathrm{L}^{-1}\right)$ & $0.089 \pm 0.00$ & $0.11 \pm 0.00$ & $0.22 \pm 0.00$ & $0.13 \pm 0.00$ & $1.10 \pm 0.09$ & $0.27 \pm 0.08$ & $11.37 \pm 0.12$ & $13.14 \pm 1.12$ & $0.3 \mathrm{mg} \mathrm{L}^{-1}$ \\
\hline $\mathrm{SO}_{4}^{-}\left(\mathrm{mg} \mathrm{L}^{-1}\right)$ & $68.06 \pm 2.98$ & $62.36 \pm 0.74$ & $32.45 \pm 0.06$ & $21.04 \pm 0.06$ & $17.01 \pm 1.01$ & $35.07 \pm 0.09$ & $11.79 \pm 0.48$ & $10.51 \pm 2.03$ & $400 \mathrm{mg} \mathrm{L}^{-1}$ \\
\hline $\mathrm{PO}_{4}{ }^{3-}$ & $0.78 \pm 0.01$ & $0.90 \pm 0.03$ & $0.29 \pm 0.00$ & $0.41 \pm 0.06$ & $\mathrm{ND}$ & $0.68 \pm 0.05$ & $\mathrm{ND}$ & $\mathrm{ND}$ & $5 \mathrm{mg} \mathrm{L}^{-1}$ \\
\hline Cobalt & $\mathrm{ND}$ & $\mathrm{ND}$ & ND & $\mathrm{ND}$ & $\mathrm{ND}$ & $\mathrm{ND}$ & $\mathrm{ND}$ & $\mathrm{ND}$ & / \\
\hline $\mathrm{Cr}$ & $\mathrm{ND}$ & $\mathrm{ND}$ & $\mathrm{ND}$ & $\mathrm{ND}$ & ND & ND & $\mathrm{ND}$ & ND & $5 \mu \mathrm{g} \mathrm{L}^{-1}$ \\
\hline $\mathrm{Pb}$ & $\mathrm{ND}$ & $\mathrm{ND}$ & $\mathrm{ND}$ & $\mathrm{ND}$ & $\mathrm{ND}$ & $\mathrm{ND}$ & $\mathrm{ND}$ & ND & $10 \mu \mathrm{g} \mathrm{L}^{-1}$ \\
\hline $\mathrm{Cd}$ & $\mathrm{ND}$ & $\mathrm{ND}$ & $\mathrm{ND}$ & $\mathrm{ND}$ & $\mathrm{ND}$ & $\mathrm{ND}$ & $\mathrm{ND}$ & $\mathrm{ND}$ & $5 \mu \mathrm{g} \mathrm{L}^{-1}$ \\
\hline
\end{tabular}

$\mathrm{ND}=$ Not Detected or below detection limit in the conditions of analy ses 
Res. J. Soil and Water Manage., 1 (3-4): 85-90, 2010

Table 2: Bacteriological quality of groundwater from eight localities

\begin{tabular}{|c|c|c|c|c|c|c|c|c|c|}
\hline \multirow[b]{2}{*}{ Microorganisms } & \multicolumn{9}{|l|}{ Villages } \\
\hline & $\begin{array}{l}\text { Goumdjel } \\
\text { Troua }\end{array}$ & $\begin{array}{l}\text { Goumdjel } \\
\text { Pastoral }\end{array}$ & $\begin{array}{l}\text { Walde } \\
\text { Sodepa }\end{array}$ & Mbe & Meiganga & Tignere & $\begin{array}{l}\text { Belel } \\
\text { Chefferie }\end{array}$ & Belel Ecole & Norm \\
\hline Total flora (CFU mL $\left.\mathrm{mL}^{-1}\right)$ & $1.54 \times 10^{4}$ & $3.00 \times 10^{4}$ & $1.3 \times 10^{3}$ & $1.5 \times 10^{2}$ & $1.25 \times 10^{2}$ & $5.9 \times 10^{2}$ & $2.6 \times 10^{5}$ & $1.7 \times 10^{5}$ & 10 \\
\hline Sulfite reducing clostridia (CFU/5 mL) & 0 & 0 & 0 & 0 & 7 & 0 & 25 & 0 & Absence \\
\hline Fecal coliforms (CFU/100 mL) & $1.7 \times 10^{3}$ & $6.9 \times 10^{3}$ & 0 & 0 & 0 & 30 & $1.3 \times 10^{2}$ & $1 \times 10^{2}$ & Absence \\
\hline Fecal streptocci (CFU/100 mL) & 0 & 0 & 0 & 0 & 0 & 0 & 14 & 12 & Absence \\
\hline Salmonella/Shigella (CFU/100 mL) & 0 & $2.3 \times 10^{3}$ & 0 & 0 & 0 & 0 & 25 & 30 & Absence \\
\hline Vibrio (CFU/100 mL) & 0 & 0 & 0 & 0 & 0 & 0 & 0 & 0 & Absence \\
\hline Pseudomonas aeruginosa (CFU/100 mL) & 0 & 0 & 0 & 0 & 0 & 0 & 0 & 0 & Absence \\
\hline Staphylococcus aureus (CFU/100 $\mathrm{mL})$ & 0 & 0 & $1 \times 0^{2}$ & 0 & 0 & 0 & 0 & 0 & Absence \\
\hline
\end{tabular}

lowest value was $6.21 \pm 0.04 \mathrm{mg} \mathrm{L}^{-1}$ for Meiganga. All samples were within the maximum permissible limit (200 $\mathrm{mg} \mathrm{L}^{-1}$ ) set by WHO. Similarly, magnesium (between $11.90 \pm 0.90 \mathrm{mg} \mathrm{L}^{-1}$ for Belel Ecole and $107.72 \pm 0.15 \mathrm{mg} \mathrm{L}^{-1}$ for Tignere) and sulfates (between $10.51 \pm 2.03 \mathrm{mg} \mathrm{L}^{-1}$ for Belel Ecole and $68.06 \pm 2.98 \mathrm{mg} \mathrm{L}^{-1}$ ) were lower than the respective WHO maximum limits of 150 and $400 \mathrm{mg} \mathrm{L}^{-1}$.

The concentration of chloride ion ranged from $7.23 \pm 0.75 \mathrm{mg} \mathrm{L}^{-1}$ (for Mbe) to $31.82 \pm 0.81 \mathrm{mg} \mathrm{L}^{-1}$ (Goumdjel Troua). The level of chloride is lower than the WHO highest desirable limit $\left(200 \mathrm{mg} \mathrm{L}^{-1}\right)$.

For iron, worrisome values were determined for three samples: Belel Ecole (13.14 $\left.\pm 1.12 \mathrm{mg} \mathrm{L}^{-1}\right)$, Belel Chefferie (11.37 $\left.\pm 0.12 \mathrm{mg} \mathrm{L}^{-1}\right)$ and Meiganga $\left(1.10 \pm 0.09 \mathrm{mg} \mathrm{L}^{-1}\right)$. This present high risk to consumers and could probably be due to the ferralitic nature of the Adamawa soils.

Very low $\mathrm{PO}_{4}{ }^{3-}$ was measured for 5 samples. The concentrations were between $0.29 \pm 0.00 \mathrm{mg} \mathrm{L}^{-1}$ (Walde Sodepa) and $0.90 \pm 0.03 \mathrm{mg} \mathrm{L}^{-1}$ (Goumdjel Pastoral) and far below the permissible limit $\left(5 \mathrm{mg} \mathrm{L}^{-1}\right)$. The low phosphate indicates that contamination from agriculture inputs is not virtually important. Interestingly, the heavy metals screened (cobalt, chromium, lead and cadmium) were not detected. The absence of these heavy metals is very positive for the quality of groundwater from the Adamawa region and for their use as drinking water. It is another sign of the very low level, even total absence of chemical pollution in rural areas of the region of study.

Different bacteria were screened and numbered to assess the microbiological quality of the water. The eight samples showed variable amounts of total flora and pathogens (Table 2). The total viable cell count showed that samples from Meiganga, Mbe and Tignere had the lowest count with, respectively $1.25 \times 10^{2}, 1.5 \times 10^{2}$ and $5.9 \times 10^{2} \mathrm{CFU} \mathrm{mL} \mathrm{mL}^{-1}$. The highest count was for Belel Chefferie $\left(2.6 \times 10^{5} \mathrm{CFU} \mathrm{mL}^{-1}\right)$. In general the five water samples collected around the Belel village contained more total flora than the other samples. Total viable count gives a picture of the safety of the samples. At the whole, none comply with existing norms $\left(10 \mathrm{CFU} \mathrm{mL}^{-1}\right)$. The high total flora for Belel samples could be explained by the presence of fecal coliforms (Goumdjel Troua), fecal coliforms and Salmonella/Shigella (Goumdjel Pastoral), fecal coliforms, sulfite reducing clostridia, fecal streptococci and salmonella/shigella (Belel Chefferie) and fecal coliforms, fecal streptococci and salmonella/shigella (Belel Ecole). The presence of such bacteria in drinking water must be considered as harm to human health since they are associated with food toxi-infections. Fecal coliforms and Fecal streptococci is an indication of fecal contamination due to human or animal fecal wastes (Rompre et al., 2002). The difference in fecal contaminants counts between the samples could be due to the level and intensity of animal husbandry activities in the localities. In this light, Belel is one of the most vital cattle breeding centers in the Adamawa region and host significant ranches with hundreds herds and thousands cows.

All samples showed negative results for the presence of Vibrio and Pseudomonas aeruginosa. The first bacterium is associated with cholera, one of the worst virulent diarrheas causing agent. Vibrio is generally found in saline water and their presence in fresh water is mostly due to contamination by animal feces. The second is a gram negative pathogen which is more virulent to immune-compromised persons such as HIV positive persons. The presence of Pseudomonas aeruginosa is also believed to be due to contamination by humans (Rosenberg, 2003).

A correlation study between samples showed that significant positive correlations exist between Goumdjel Troua, Goumdjel Pastoral, Walde Sodepa, Belel Chefferie and Belel Ecole (Table 3).

Similarly, significant correlations were also obtained between water samples from Mbe, Tignere and Meiganga. These two groups of samples are confirmed by the Principle Component Analysis (PCA) of the eight groundwater samples based on the physico-chemical and bacteriological composition (Fig. 2). Clearly the PCA 
Res. J. Soil and Water Manage., 1 (3-4): 85-90, 2010

Table 3: Correlations between water samples from the eight localities

\begin{tabular}{|c|c|c|c|c|c|c|c|c|}
\hline Variables & Goumdjel Troua & Goumdjel Pastoral & Walde Sodepa & Mbe & Meiganga & Tignere & Belel Chefferie & Belel Ecole \\
\hline Goumdjel Troua & $1^{*}$ & $0.99^{*}$ & $0.98^{*}$ & 0.55 & 0.23 & 0.35 & $0.99^{*}$ & $0.99^{*}$ \\
\hline Goumdjel Pastoral & - & $1.00^{*}$ & $0.95^{*}$ & 0.52 & 0.20 & 0.32 & $0.97^{*}$ & $0.97^{*}$ \\
\hline Walde Sodepa & - & - & $1.00 *$ & 0.65 & 0.32 & 0.44 & $0.98 *$ & $0.98^{*}$ \\
\hline Mbe & - & - & - & $1.00 *$ & $0.91^{*}$ & $0.94 *$ & 0.55 & 0.56 \\
\hline Meiganga & - & - & - & - & $1.00^{*}$ & $0.99 *$ & 0.22 & 0.22 \\
\hline Tignere & - & - & - & - & - & $1.00^{*}$ & 0.34 & 0.34 \\
\hline Belel Chefferie & - & - & - & - & - & - & $1.00^{*}$ & $1.00^{*}$ \\
\hline Belel Ecole & - & - & - & - & - & - & - & $1.00^{*}$ \\
\hline
\end{tabular}

Values with *indicate a significant correlation between two samples at $5 \%$ level

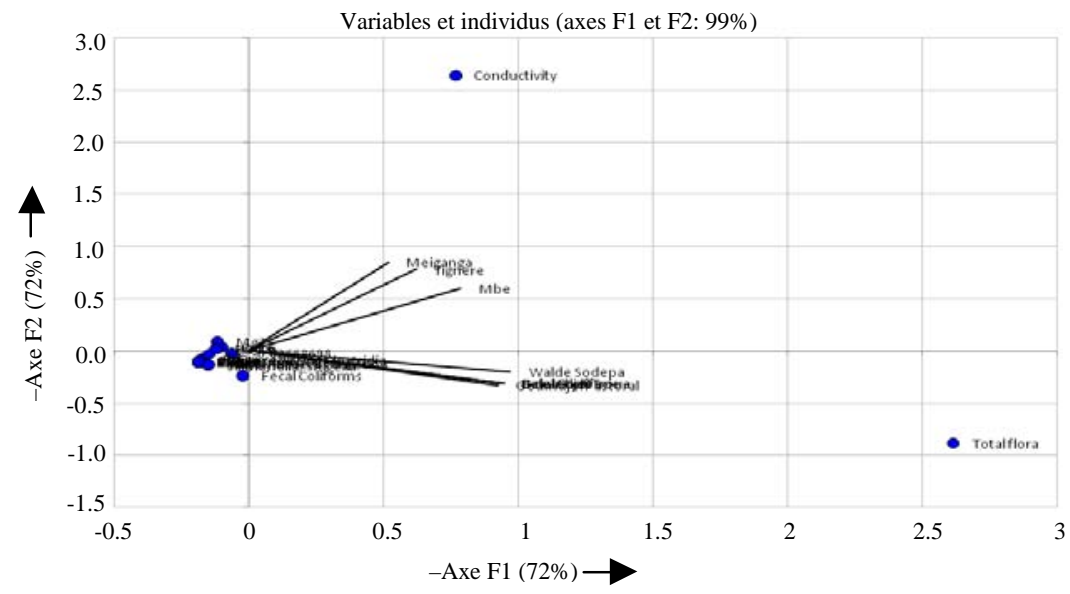

Fig. 2: The principal component analysis profile of the 8 groundwater samples based on their physco-chemical characteristics and microbiological composition

opposes two groups of samples: the first group is made up of highly correlated samples with high total flora and the second group comprises samples with low total flora and which are also correlated between them by the similarity of their physic-chemical properties.

\section{CONCLUSION}

The study of groundwater from eight improved wells drilled in the Adamawa region of Cameroon revealed a globally satisfying physico-chemical feature. For most parameters studied except for turbidity, samples fell in the conventional admissible limits indicating the low impact of human activity on the chemical content. Generally, the water was not contaminated by heavy metals. However, the microbiological quality of all samples is questionable. Pathogens and indicators were detected and numbered at significant amounts for some samples. The comparison of wells helped in distinguishing two groups of samples. Those collected in areas with high cows concentrations appeared most contaminated by bacteria. This study challenges the general opinion in rural areas who believes that water from covered and improved wells is safe and could be used without any treatment.

\section{REFERENCES}

APHA, AWWA and WEF, 1999. Standard Methods for the Examination of Water and Wastewater. 20th Edn., American Public Health Association, American Water Works Association and Water Environment Federation, Washington DC, USA.

Ako, A.A., G.E. Nkeng and G.E. Takem, 2009. Water quality and occurrence of water-borne diseases in the Douala 4th district, Cameroon. Water Sci. Technol., 59: 2321-2329.

Ali, A., D. Ahmadou, B.A. Mohamadou, C. Saidou and D. Tenin, 2010. Determination of minerals and heavy metals in water, sediments and three fish species (Tilapia nilotica, Silurus glanis and Arius parkii) from Lagdo Lake, Cameroon. J. Fish. Int., 5: 54-57.

European Drinking Water Directive, 1998. Europe council directive $98 / 83 / \mathrm{EC}$ on the quality of water intended for human consumption. Official J. Eur. Commun., L330: $32-54$.

Garba, C.M.G. and C.M.F. Mbofung, 2010. Relationship between malnutrition and parasitic infection among school children in the Adamawa Region of Cameroon. Pak. J. Nutr., 9: 1094-1099. 
Nkansah, M.A., J. Ofosuah and S. Boakye, 2011. Quality of groundwater in the kwahu West district of ghana. Environ. Res. J., 5: 31-37.

Rompre, A., P. Servais, J. Baudart, M. de Roubin and P. Laurent, 2002. Detection and enumeration of coliforms in drinking water: Current methods and emerging approaches. J. Microbiol. Methods, 49: 31-54.
Rosenberg, F.A., 2003. The microbiology of bottled water. J. Clin. Microbiol., 25: 41-44.

WHO, 1998. Guidelines for Drinking-Water Quality. Vol. 2, Health Criteria and Other Supporting Information. World Health Organization, Geneva. 